\title{
The Voices of Women: A New Force Shaping the Guatemalan Return
}

\author{
Frances Arbour ${ }^{1}$
}

For much of the more than twelve years in which Guatemalans have been refugees in Mexico, the voices of women were not heard. Most of those who fled to southern Mexico were indigenous peasant women, who were often illiterate and spoke only indigenous languages. Unable to communicate in Spanish, they became isolated and had little contact with the United Nations High Commissioner for Refugees (UNHCR), the Mexican authorities, the international community or the local groups offering solidarity.

After the 1986 election of civilian president Vinicio Cerezo, there was mounting pressure for the refugees to return to Guatemala. The president's wife, Raquel Blandon de Cerezo, visited the camps in November 1986 to tell the refugees that conditions had changed in their country so they could forget what had happened and return home. Many of the widows responded with a letter asking that those responsible for their husbands' deaths and disappearances be brought to justice. Shortly thereafter, the refugees elected the Permanent Commissions of Guatemalan Refugees in Mexico to begin negotiations aimed at guaranteeing a safe and dignified return. In those first elections, two of the eight representatives chosen for the Permanent Commissions were women.

\section{New Opportunities Develop Confidence}

Gradually, more and more Guatemalan refugee women have become actively involved in directing life in their camp communities, as well as preparing organized, collective returns. At times, it has been a slow and difficult

Frances Arbour served as Program Coordinator for Guatemala and Mexico for Project Counselling Services for Latin American Refugees (1988-93) process; at other times, creative and dynamic. The experience has provided a diversity of opportunities for the women, such as learning to read and write, and to speak Spanish. Supported by resources from the UNHCR and a number of international cooperation agencies, some of the women have also been trained to teach literacy to other refugee women. All of this has led to the development of both consciousness and self-confidence.

A growing number of women participate in projects such as health and nutrition, family gardens and raising animals, traditional weaving to maintain their rich Mayan cultural heritage and larger cooperative production projects, including the cultivation of fruit for commercial markets. The women have demanded adequate technical training to carry out these tasks effectively and have been aided by local nongovernmental organizations.

\section{Training to Eliminate Dependency}

Many of the women participating in productive projects also have requested administrative training to enable them to carry out all aspects of their work, including financial management, without having to depend on refugee men. But taking on additional tasks often places an unbearable burden on women who must continue to look after their traditional responsibilities within the family. To manage, the women have sought time-saving measures such as cooperative, mechanized tortilla making and cooperative child care. These measures allow the women to participate more fully in political, organizational, productive and other important activities.

Throughout this process, the women have become increasingly conscious of their rights as women within Mayan culture. Non-Mayan women also probe gender issues from their mestizo standpoint and together they are deepening their organizational work. It is an ongoing and profound process, in which the women have come to understand the many subtle and not-so-subtle ways in which, traditionally, they have been marginalized from broader community participation and decision-making.

\section{Women's Organizations Receive Less Funding}

Over time, Guatemalan refugee women have built a number of organizations, with characteristics which vary according to the backgrounds and experiences of those involved. Such organizing has taken place with minimal material support. Traditional funding bodies have provided less resources for women's projects than for mixed or community projects, despite rhetoric about supporting women.

The first Guatemalan refugee women's organization to present a public face was the now well-known Mama Maquin, founded on May 25, 1990. Their name honours the memory of a Kekchi woman assassinated by the Guatemalan military in a 1978 massacre of indigenous peasants seeking land rights. Today, Mama Maquin represents about eight thousand refugee women from eight different indigenous groups who live in refugee camps in Chiapas, Campeche and Quintana Roo. Mama Maquin played a vital role in the first and second organized returns, which took place in January 1993 and January 1994. The group represents 670 women returnees in the first return community, Victoria 20 de enero, located in the Quiche province, in northern Guatemala. Mama Maquin works primarily with the Permanent Commissions who are organizing returns to the northwestern zones of Guatemala. 
At the beginning of the 1990s, another group of Guatemalan refugee women founded La Nueva Union, based primarily in Campeche. Slowly, they merged with a number of smaller refugee women's organizations in Chiapas, Quintana Roo and their original base in Campeche, to form the Union de Mujeres Guatemaltecas Para el Futuro de Guatemala in 1993. Together with the Permanent Commissions, many of the Union members are actively organizing the collective returns to northern Guatemala, particularly to the Peten and Alta Verapaz. From the beginning, this group has demanded to send their representatives with the special commissions seeking land options for the returnees. They believe that the women's perspective is particularly important in choosing where the return communities should be located, as well as what model of development and community organization should be implemented.

On November 26, 1993 about six hundred refugee women from the "Union de Mujeres". who identify more closely with the northern sector returns founded the newest Guatemalan refugee women's organization, "IXMUCANE." One of IXMUCANE's objectives is to organize in order to achieve full participation in the preparation for the returns to northern Guatemala, particularly to the Petén and Alta Verapaz. They are preparing themselves to participate in all the structures of their future communities in Guatemala.

"Madre Tierra," another Guatemalan refugee women's organization formally appeared in August 1993. Its members are primarily, although not exclusively, Mayan women whose po- litical consciousness was raised during years of grass roots organizing, training health promoters and midwives, and participating in a variety of projects. The reflective work which accompanied these projects led the women to formally organize themselves in order to deepen their gender consciousness and strengthen their capacity to participate at all levels of community life. At their inauguration, they represented approximately eight hundred refugee women in the states of Quintana Roo, Campeche and Chiapas. Madre Tierra has continued to grow and is now participating actively in preparation for returns to the southern areas of Guatemala.

\section{Women Strongly Represented Outside UNHCR Camps}

While there are forty-three thousand refugees living in UNHCR-recognized camps in southern Mexico, at least three times as many Guatemalan refugees are dispersed outside those camps. Women make up the majority of these dispersed refugees. Their situation has always been precarious as the Mexican government and UNHCR have never formally recognized them as refugees and they have received only a minimum of international humanitarian assistance.

The dispersed refugees have also organized, forming the Association of Guatemalan Dispersed Refugees, known as ARDIGUA. Since its creation, women have held key leadership positions in ARDIGUA, and are strongly represented through a Women's Secretariat. The ARDIGUA women are in close contact with other Guatemalan refugee women's organizations and share with them a gender perspective. They are working primarily to organize collective returns to the southern areas of Guatemala.

The advances made by Guatemalan refugee women have not been easy. Many refugee men, accustomed to a traditional male dominated culture, have resisted the women's struggle to assume new roles and activities. However, as those activities have proved essential to organizing the collective return process, many men now welcome the new partnership.

\section{Notes}

1. This article is a revised version of a paper previously published in Americas Update, a publication of the Latin American Working Group and the Jesuit Centre for Social Faith and Justice, under the title "From silence to vocal participation: Guatemalan women shape the refugee returns."

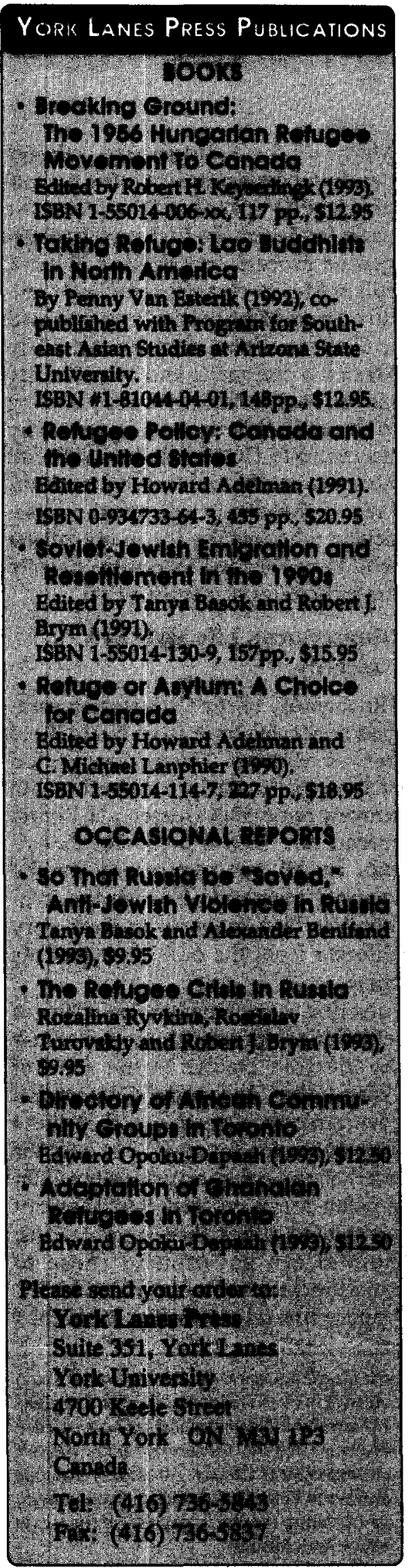

